\title{
Resolusi Konflik dalam Masyarakat Religius Indonesia
}

\author{
Alim Roswantoro \\ UIN Sunan Kalijaga - Yogyakarta \\ alimroswa@yahoo.com
}

\begin{abstract}
Indonesia, as the plural nation in religion, has already performed a positive and peaceful life of the religious people who are different in faith and understanding. In general, the life of religious people in Indonesia is lasting well and peacefully. It does not mean that there never be religious conflicts of the different religious people in Indonesia. The conflicts had ever occurred and will probably emerge in the future. The conflicts were often seen as threat, or negativity, of religious life among different-religious people in Indonesia. The writing does not deny that indeed the conflicts are not wanted and have to be overcome. But since the conflicts cannot be avoided from the life of differentreligious people of Indonesia, the writing philosophically intend to see and understand the conflicts in a different way. The religious conflicts can be positively seen and understood, that is, as part of communication among different-religious people interacting in public sphere. Conflict-resolution that gives the win-win solution for those who are involved in the conflict has to be principle that should be made to be tradition. Conflict resolution will be successful if the transcendently moral principles, such as mutual respect, mutually avoiding deformation of religion, and mutually giving freedom, are provided for all.
\end{abstract}


[Indonesia sebagai negara yang majemuk dalam agama telah menampilkan wajah hidup umat beragama dari agama-agama yang berbeda yang damai. Secara umum, kehidupan umat beragama di Indonesia berjalan dengan penuh kedamaian. Ini bukan berarti tidak pernah ada konflik keagamaan di Indonesia. Konflik-konflik keagamaan telah pernah terjadi dan mungkin akan muncul kembali di masa depan. Konflikkonflik ini sering dilihat sebagai suatu ancaman atau sisi negatif dari kehidupan religius di Indonesia. Tulisan ini tidak memungkiri bahwa konflik-konflik ini memang tidak diinginkan dan harus diatasi. Namun, karena konflik-konflik ini tidak bisa dihindari dalam kehidupan antar umat beragama yang berbeda, tulisan ini mencoba secara filosofis melihat dan memaknai konflik-konflik ini secara berbeda. Konflik-konflik keagamaan bisa dimaknai secara positif, sebagai bagian dari komunikasi antara umat beragama yang berbeda yang berinteraksi dalam ruang publik. Resolusi konflik yang saling memenangkan masing-masing pihak harus menjadi prinsip yang harus ditradisikan. Resolusi konflik akan sukses, jika prinsip-prinsip moral transenden, seperti saling menghargai, saling menghindari deformasi agama, dan saling memberi ruang kebebasan, diberikan untuk semuanya.]

Keywords: Religious conflict, conflict resolution, masyarakat religius Indonesia

\section{Pendahuluan}

Perbedaan antar agama, kepercayaan keagamaan, dan pemahaman keagamaan, berpotensi memunculkan konflik. Namun dalam beberapa hal perbedaan keagamaan mampu menjadi medium bagi orang-orang yang berbeda agama, kepercayaan keagamaan, dan pemahaman keagamaan untuk mendewasakan keberagamaan masingmasing.

Bagaimana mereka yang berbeda dalam religiusitas tidak meninggikan martabat agama dan keberagamaannya dengan cara pemaksaan kehendak dan kekerasan fisik. Hal ini merupakan pemikiran yang mengupayakan kedewasaan beragama di tengah pluralitas agama dan keagamaan. Sejalan dengan pemahaman bahwa tidak ada martabat suatu agama atau suatu kepercayaan keagamaan yang bisa ditinggikan dengan pemaksaan kehendak dan kekerasan 
fisik. Sacks mengartikulasikan hal ini dengan pernyataannya, "No religion won the admiration of the world by its capacity to inflict suffering on its enemies." (Tidak ada agama yang memenangkan kehormatan dunia dengan kemampuannya menimpakan penderitaan pada musuhmusuhnya).

Munculnya konflik keagamaan di Indonesia beberapa dekade terakhir menunjukkan bahwa potensi terjadinya konflik bisa dari beberapa faktor seperti politik, ekonomi, kultur dan sebagainya. Sehingga penting untuk memahami bagaimana kita melihat konflik dengan cara berbeda. Konflik bukan sebagai ancaman, melainkan sebagai komunikasi untuk membangun hubungan baik untuk saling memberi ruang kebebasan dan saling menghargai.

Tulisan ini merefleksikan secara filosofis konflik-konflik keagamaan yang pernah terjadi dan mungkin akan terjadi kembali di masa yang akan datang. Dilihat dari fakta positifnya, perbedaan keagamaan mampu mendewasakan keberagamaan insan religius. Namun fakta negatifnya agama bisa menjadi kekuatan yang mengancam dan meneror dunia. Menurut Mc Ternan, dalam sejarah agama, setiap agama memiliki pengalaman melakukan kekerasan atas nama agama, karena ajaran agamanya bisa dipahami untuk membenarkannya. ${ }^{2}$ Namun seburuk-buruknya negativitas kekerasan atas nama agama, Fuller menegaskan bahwa apa yang dilakukan agama tidak lebih buruk daripada yang pernah dilakukan oleh kekerasan ekstremis-ekstremis sekuler seperti fasisme, nazisme, dan komunisme. ${ }^{3}$ Fakta positif kehidupan umat beragama mengajak hidup untuk berbagi, hidup damai, dan saling mengasihi kepada sesama manusia tanpa melihat latar belakangnya banyak ditemukan dalam sejarah umat beragama hingga saat ini. Konflik-konflik keagamaan bisa saja muncul kapan pun. Sehingga bagaimana seharusnya sikap umat beragama memaknai konflik-konflik ini dan bagaimana seharusnya melakukan resolusi untuk meminimalisir kemunculannya menjadi fokus dari refleksi filosofis tulisan ini.

${ }^{1}$ Jonathan Sacks, Not in God's Name: Confronting Religious Violence (Edinburg: Hodder \& Stoughton, An Hachette UK Company, 2015), 265.

${ }^{2}$ Lihat Oliver McTernan, terutama pada bagian "Religion and the Legitimation of Violence" dalam bukunya Violence in God's Name (London: Darton, Longman Todd Ltd., 2003), 45-76.

${ }^{3}$ Graham E. Fuller, A World Without Islam (New York: Little, Brown and Company, 2010), 348 . 


\section{Multikulturalisme Religius tanpa Konflik: Mungkinkah?}

Konflik adalah bagian dari kehidupan manusia, namun ia bukan merupakan tujuan dari kehidupan manusia. M. Amin Abdullah menyebut bahwa konflik adalah min lawazim al-hayah (konflik adalah bagian dari kewajaran hidup). "Dalam era apapun, di mana pun dan kapan pun umat manusia tidak pernah terbebas dari konflik, pertengkaran dan perselisihan." "Konflik selalu mewarnai kehidupan manusia baik secara pribadi maupun kolektif. Ia bisa terjadi dalam kehidupan diri pribadi manusia, dalam kehidupan keluarga, dalam kehidupan masyarakat, baik sosial, budaya, politik maupun agama. Orang secara perorangan sering terlibat konflik dengan dirinya sendiri, atau sering disebut orang dengan konflik batin atau konflik kejiwaan.

Motivasi orang untuk tetap bisa bangkit dan bertahan hidup adalah kebutuhan-kebutuhan hidupnya, ${ }^{5}$ mulai dari pemenuhan kebutuhan pokok seperti makan, sandang, dan papan, sampai kebutuhan non-pokok seperti pasangan hidup, hiburan, ekspresi seni, dan lain sebagainya. Setiap orang memiliki cara yang berbeda untuk memenuhi kebutuhannya, sehingga potensi konflik bisa berawal dari sini. Hal ini menjadi masuk akal karena banyak kebutuhan yang ingin diwujudkan, dalam proses pewujudan kebutuhan-kebutuhan, tersembunyi di dalam diri mereka kepentingan-kepentingan yang bersifat pribadi, sosial, budaya, keagamaan, bahkan politik. Poitras dan Renaud menyebut kenyataan ini sebagai wajar, dan bahkan keduanya memandang mustahil ada kehidupan tanpa konflik. Kedua pemikir ini, dalam pendahuluan bukunya menyatakan,

"It would be utopian to think that countries with millions of inhabitants could go forever without any sort of conflict arising. We all have different interests, and every public project or policy, be it local or national in scope, impacts directly or indirectly on those interests. Similarly, a dispute which initially private may become public if it extends beyond the immediate parties. “6

\footnotetext{
${ }^{4}$ M. Amin Abdullah, "Peran Pemimpin Politik dan Agama dalam Mengurai dan Resolusi Konflik dan Kekerasan" dalam Alim Roswantoro dan Abdul Mustaqim (ed.), Antologi Isu-isu Global dalam Kajian Agama dan Filsafat (Yogyakarta: Prodi Agama dan Filsafat Pascasarjana UIN Sunan Kalijaga dan Penerbit Idea Press, 2010), 1.

${ }^{5}$ Henry Murray, Explorations in Personality (New York: Oxford University, 1938), $77-$ 79 .

"Jean Poitras and Pierre Renaud, "Introduction," dalam Mediation and Reconciliation of Interest in Public Disputes (Ontario: Carswell Thomson Professional Publishing, 1997), 1.
} 
(Akan menjadi angan-angan kosong untuk berpikir bahwa negara-negara dengan berjuta-juta penduduk dapat melangsungkan hidupnya tanpa adanya konflik. Kita semua memiliki kepentingankepentingan yang berbeda-beda, dan setiap proyek atau kebijakan publik, apakah ia dalam lingkup lokal atau nasional, secara langsung atau tidak langsung berpengaruh pada kepentingan-kepentingan tersebut. Sama halnya, suatu percekcokan yang awalnya bersifat pribadi bisa menjadi publik jika ia meluas melampaui kelompokkelompok sosial yang ada).

Di masa lalu, berbagai konflik religius telah terjadi di Indonesia, baik konflik antar perbedaan pemahaman atau konflik keyakinan dalam suatu agama tertentu serta konflik antar agama, hal ini menunjukkan bahwa pendapat Poitras dan Renaud benar dengan fakta tidak mungkin menjalani kehidupan religius yang berbeda-beda di Indonesia tanpa konflik-konflik religius. Masa mendatang memang belum terjadi, namun tidak ada jaminan masa yang akan datang hubungan hidup antar agama dan antar kepercayaan di Indonesia akan steril dari konflik-konflik religius.

Ada dua kemungkinan apakah multikulturalisme religius bisa dijalankan tanpa konflik. Pertama, utopia karena dilihat dari faktanya konflik religius tidak mungkin bisa dihindari di tengah kehidupan masyarakat yang ragam agama dan budaya. Kedua, bisa terjadi multikulturalisme tanpa konflik selama insan religius mendorong dirinya sendiri dan orang-orang religius di sekitarnya untuk selalu mempersiapkan diri mengantisipasi adanya konflik dengan cara yang mampu menurunkan eskalasi (deescalation) dan mengatasi konflik secara damai serta komunikatif. Ketika kehidupan religius dalam keadaan damai dan harmoni, upaya strategis untuk memperbanyak manusia-manusia religius dengan karakter selalu respek, toleran, dan berlapang dada terhadap komunitas agama lain, sering luput untuk dilakukan. Ada pendapat tentang bom waktu tersembunyi yang siap mengubah keadaan religiusitas, sehingga setiap umat beragama berperan untuk mengantisipasi hal tersebut. Dengan cara demikian, konflik religius seolah mengatakan pada kita bahwa harmoni dan kedamaian religius antar umat beragama bukan merupakan sesuatu yang didapat, melainkan sesuatu yang terus diperjuangkan.

\section{Konflik dan Kebijaksanaan Pembelajaran Keberagamaan}

Bagi Fiadjoe, secara potensial ada tiga hal yang menjadi asal-usul munculnya konflik, yaitu nilai-nilai yang berbeda, kebutuhan- 
kebutuhan dasar yang tak terpenuhi, sumber-sumber yang terbatas. Pertama meliputi keyakinan-keyakinan, prioritas-prioritas, prinsipprinsip, dan kepercayaan-kepercayaan. Kedua mencakup kepemilikan, kekuasaan, kebebasan, dan kesenangan. Sementara yang ketiga, atau sumber-sumber terbatas yang dimiliki manusia meliputi waktu, uang, dan barang-barang yang dimiliki. ${ }^{7}$ Bagan di bawah menjelaskan tentang The origins of conflict menurut Fiadjoe:

\section{Bagan Asal-usul Konflik ${ }^{8}$}

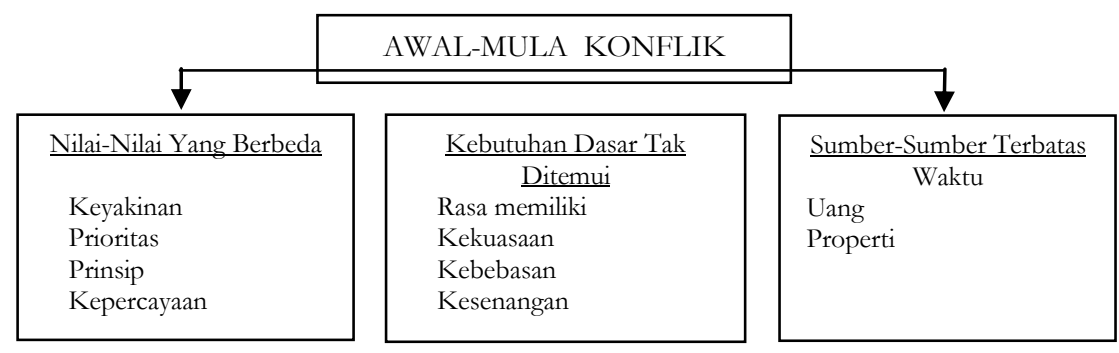

Pandangan Watkins, seperti dikutip oleh Robbi I. Candra, ada dua hal penyebab terjadinya suatu konflik. Pertama, secara potensial dan praktis/operasional, pihak-pihak yang terlibat memiliki kemampuan untuk saling menghambat, sehingga dengan jalan demikian konflik bisa terjadi. Kedua, konflik bisa terjadi apabila ada suatu sasaran yang sama-sama dikejar, namun hanya satu yang pada akhirnya harus mendapatkannya. Contoh untuk yang pertama, ada dua institusi sekolah agama yang berbeda aliran, dalam suatu wilayah yang sama, dan berebut untuk mendapatkan murid. Untuk tujuan ini, kedua belah pihak sama-sama memiliki potensi untuk melakukan aksiaksi penghambatan publik untuk tidak memilih sekolah yang menjadi pesaing, misanya dengan membuat provokasi-provokasi tentang kelemahan sekolah melalui sosialisasi publisitas sekolah. Sementara contoh untuk yang kedua, tentang dua orang yang menjadi kandidat suatu jabatan penting dalam suatu perusahaan. Perusahaan hanya membutuhkan salah satu di antara keduanya. Persaingan ini bisa berkembang menjadi konflik. Karena pihak manajemen perusahaan tidak mungkin memenuhi keinginan keduanya sekaligus, maka keduanya secara potensial dapat terlibat dalam suatu konflik.

\footnotetext{
${ }^{7}$ Albert Fiadjoe, Alternative Dispute Resolution: A Developing World Perspective (London. Sydney, Portland, Oregon: Cavendish Publishing Limited, 2004), 9.

${ }^{8}$ Ibid. 10

${ }^{9}$ Robby I. Chandra, Konflik dalam Hidup Sehari-hari (Yogyakarta: Penerbit Kanisius, 1992), 20-21.
} 
Konflik-konflik yang terjadi, umumnya berawal dari konflik tingkat antar individu, kemudian berkembang antar kelompok, organisasi, partai-partai, etnis, agama, dan bahkan antar masyarakat yang lebih besar cakupannya. Ragam individu, organisasi, partai, etnis, agama dan kelompok-kelompok sosial lain yang terlibat semakin meningkat dan lingkup yang dipertentangkan juga berkembang kompleks mulai dari masalah ekonomi, sosial, dan lingkungan. Intensitas pertentangan yang semakin eskalatif dan rumit menggambarkan suatu dinamika konflik. Dinamika konflik dan situasinya ditentukan oleh isu-isu yang mendasari pertentangan, seperti kepentingan-kepentingan yang berseberangan atau cara-cara yang berlawanan dirasakan, dipahami, dan diperdebatkan oleh banyak orang dengan latar sosial, budaya, politik, ekonomi dan keagamaan yang berbeda-beda dalam rangka memuaskan suatu kepentingan umum bersama. Dinamika konflik yang berkembang sangat kompleks tentu membutuhkan penanganan manajemen yang rumit pula dan memakan waktu lama dalam menegosiasikan, memediasi, dan mengkomunikasikan kemungkinan-kemungkinan terbaik dengan prinsip sebesar mungkin keuntungan dan sekecil mungkin kerugian yang dirasa semua pihak. Memahami dinamika konflik, dengan demikian, bisa diperhatikan dari:

1. Aspek kepentingan-kepentingan, tujuan-tujuan, dan nilai-nilai apa yang dipertentangkan oleh kedua belah pihak yang berselisih.

2. Siapa-siapa saja yang berperan dan memainkan masalah-masalah yang dipertentangkan oleh kedua belah pihak yang berselisih.

3. Bagaimana alat-alat dan sumber-sumber, desain, dan tabel waktu yang dipertentangkan oleh kedua belah pihak yang berselisih. 


\section{Bagan Dinamika Konflik ${ }^{10}$}

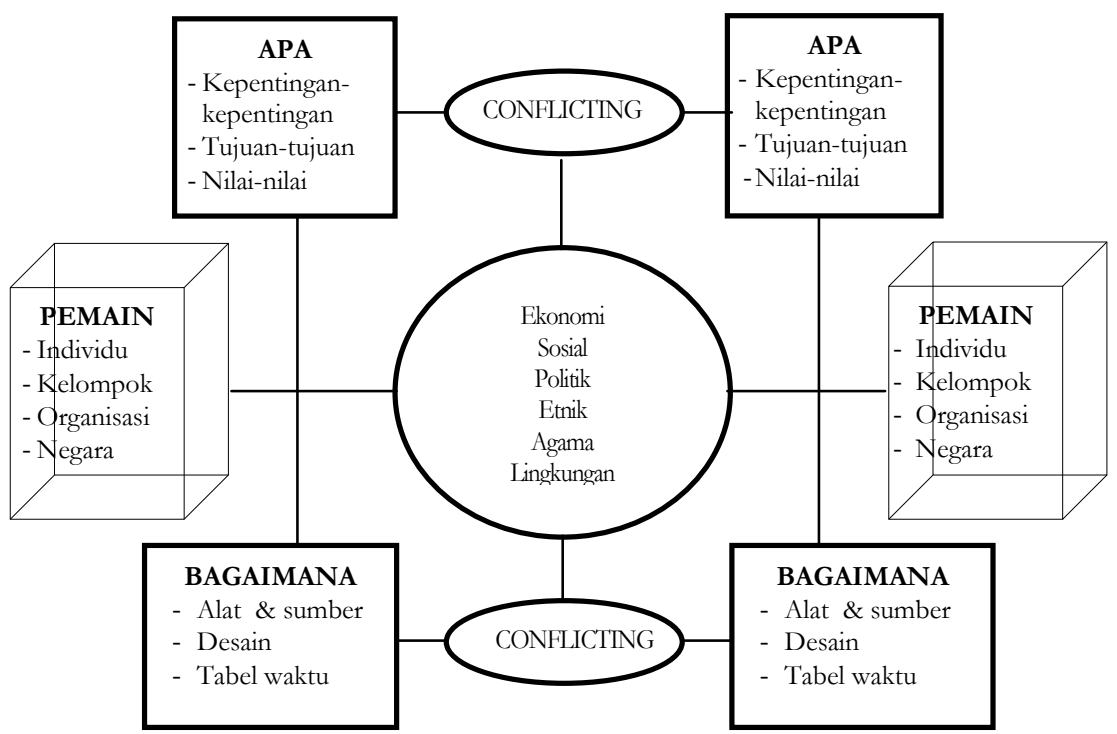

Konflik adalah sesuatu yang bergerak, bukan sesuatu yang statis. Gerakan eskalatif atau deeskalasi nya bisa bervariasi, yang jelas kadang-kadang dalam keadaan laten dan kadang-kadang manifes. Semakin lama konflik tidak diantisipasi dan ditangani dengan baikefektif, semakin kompleks dan rumit konflik dan semakin terbuka lebar pada terjadinya kekerasan dan perang. Eskalasi konflik merupakan tanda adanya kegagalan suatu resolusi konflik. Jadi konflik bukanlah hal yang harus dilihat secara statis, melainkan dinamis. Lihat eskalasi konflik dalam bagan berikut:

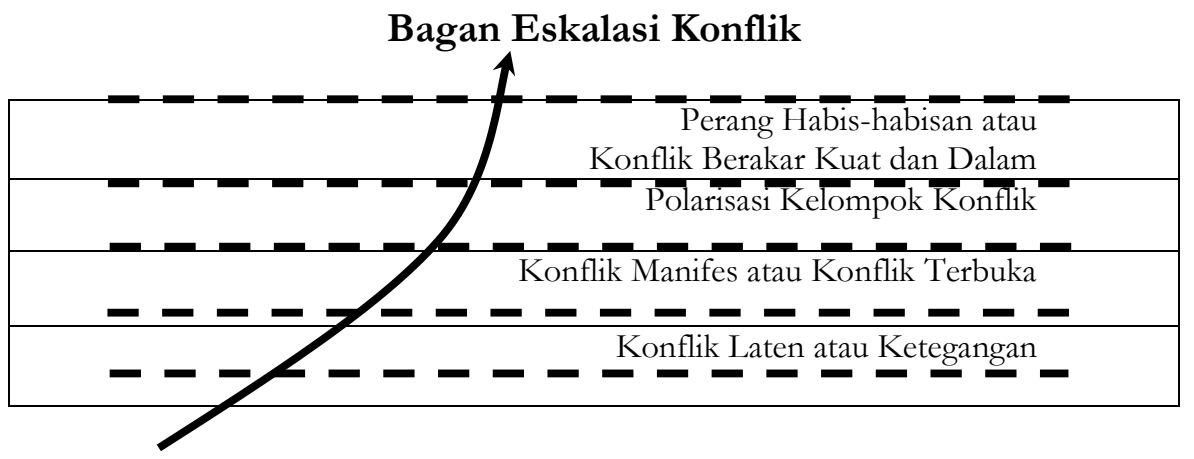

${ }^{10}$ Bagan ini diambil dari Jean Poitras and Pierre Renaud, Mediation and Reconciliation of Interest in Public Disputes (Ontario: Carswell Thomson Professional Publishing, 1997), 9, dengan sedikit modifikasi. 
Beragama merupakan kebutuhan hidup manusia. Meskipun tidak semuanya, namun tidak salah mengatakan bahwa kebanyakan manusia memerlukan agama. Beragama bukan merupakan kebutuhan material manusia, namun merupakan kebutuhan spiritual manusia. Mendasarnya kebutuhan ini bagi nilai dan makna kehidupan orang, dan karena ragam agama dan kepercayaan yang dipegangi, kehidupan beragama dari komunitas-komunitas umat yang ragam agama dan kepercayaan rentan terhadap terjadinya konflik. Konflik-konflik religius, boleh dibilang tidak jauh beda dari konflik-konflik manusia pada umumnya, seperti dalam penjelasan Fiadjoe di atas, muncul dari perbedaan nilai, dari tidak terpenuhinya kebutuhan dasar, dan sumber-sumber yang terbatas.

Konflik-konflik religius muncul dari perbedaan nilai terutama nilai kepercayaan. Bagi agama tertentu memandang patung yang disembah dalam suatu agama sebagai berhala yang tidak suci, sementara bagi agama yang meyakini memandangnya suci. Dalam wilayah pribadi keyakinan yang memandangnya tidak suci tidaklah menjadi soal, namun ketika dilontarkan dalam ranah publik bisa menyinggung keyakinan yang memandangnya suci, dan bisa menimbulkan konflik religius antara yang tidak meyakini dan yang meyakini. Konflik-konflik religius muncul dari tidak terpenuhinya kebutuhan-kebutuhan dasar, seperti kebebasan menjalankan keyakinan dan ritual agama dan kebebasan mendirikan tempat ibadah. Problem ini sangat menonjol di negara-negara yang multi agama. Problem kesulitan mendirikan tempat sembahyang di Indonesia bagi warga kristiani banyak terjadi di tengah-tengah komunitas yang mayoritas muslim. Di daerah lain, seperti di Bali, bagi warga muslim juga tidak mudah dan serta merta bisa mendirikan tempat ibadah di sembarang tempat; hal yang sama juga bisa ditemukan di Papua, Manado dan daerah-daerah lain yang mayoritasnya adalah kristiani.

Secara umum, warga kristiani barangkali mengalami kesulitan mendirikan tempat sembahyang di Indonesia, tetapi harus diingat juga tidak mudah bagi warga muslim di Eropa dan di Amerika bisa mendirikan tempat ibadah atau islamic center. Pemenuhan kebutuhan dasar religius sering terhalang dengan problem mayoritas-minoritas. Konflik-konflik religius muncul dari sumber-sumber yang terbatas. Sumber-sumber terbatas bisa berupa uang atau dana yang melimpah mungkin bisa dimiliki baik yang minoritas dan mayoritas, ketika penggunaannya yang tidak menimbang perasaan yang lain tentu bisa memicu konflik, bisa juga berupa sedikitnya penganut, sehingga 
kurang kuasa dalam menghadapi hambatan dari pihak yang banyak penganut.

Konflik religius yang berasal dari tiga sumber tersebut muncul hanya jika ada pihak-pihak religius yang satu memberikan hambatan bagi pihak religius lainnya. Jika kedua pihak religius saling menghambat dan terus mengembangkan hambatan-hambatan, dari teori Watskin di atas, maka konflik religius menjadi semakin eskalatif dan bisa terus memanas berkembang menjadi konflik fisik. Mungkin awal konfliknya antar individu yang berbeda agama. Jika mereka saling memprovokasi yang bernada penistaan agama, maka konflik bisa berkembang menjadi konflik religius yang bersifat antar kelompok. Ini karena provokasi dari masing-masing individu di dalam komunitas religiusnya masing-masing bekerja dan berhasil memancing emosi kelompoknya. Jika pekerjaan saling menghambat dari kedua belah pihak terus dibiarkan berkembang, maka konflik religius yang bersifat terbuka dan meluas bisa terjadi. Pada tahap selanjutnya, konflikkonflik religius dengan kepentingan, prinsip, dan nilai kepercayaan yang berbeda bisa muncul dan menambah kompleks wajah konflik religius.

Konflik bukanlah racun kehidupan, melainkan "bunga" kehidupan. Pengalaman hidup manusia memberitahu kita bahwa racun itu membahayakan dan bahkan mematikan, sementara bunga yang kita lihat di taman, selain penuh warna, dalam proses selanjutnya akhirnya ia menjadi buah yang memberi kesenangan dan kebahagiaan bagi yang memanfaatkannya. Sama halnya dengan berbagai kehidupan religius di Indonesia yang timbul-tenggelam dalam penggal-penggal ruang-waktu historis berjalan dari dulu hingga kini, bahkan selalu ada kemungkinan sampai di masa-masa sesudah sekarang. Konflik kehidupan religius antar umat beragama, baik yang intra maupun antar agama, adalah bagian dari proses kehidupan religius manusia Indonesia, yang tidak boleh dianggap oleh para pihak religius sebagai tujuan dari kehidupan religius manusia Indonesia.

Konflik-konflik religius adalah "bunga" bagi kehidupan religius manusia Indonesia. Kesadaran bahwa konflik-konflik religius merupakan bagian dari komunikasi religius antara ragam umat beragama selalu akan memberi "buah" atau hasil kehidupan religius yang lebih matang. Oleh karena itu, lebih baik bagi setiap insan religius di Indonesia merenungkan konflik-konflik religius yang pernah terjadi di Indonesia sebagai tanda yang maknanya secara semiotik harus diproduksi. Jika kehidupan religius tanpa konflik 
religius tak terhindarkan, maka apa makna yang bisa diungkapkan dari tanda seperti itu. Apakah ia menandakan bahwa agama memang merupakan sumber konflik, atau apakah ia menandakan sesuatu yang lain mengenai suatu makna hakiki dari keberagamaan? Jika yang pertama dibenarkan, lalu bagaimana dengan fakta kehidupan lain yang juga tidak berjalan tanpa konflik, apakah lalu kita mengatakan semua bidang hidup manusia adalah sumber konflik. Maka lebih arif mengambil kemungkinan yang kedua, adanya konflik religius yang kita terlibat di dalamnya berarti menandakan suatu makna mengenai apakah keberagamaan kita sudah baik. Jika kita marah, memaki-maki atas konflik religius yang terjadi, dan kemarahan dan makian ditujukan untuk pembelaan keagamaan kita, maka berarti kita di dalam ruang religius pribadi kita sedang terjadi konflik. Kita tidak bisa berdamai dan harmoni dengan diri kita sendiri. Barangkali marah dan makian akan memiliki makna yang lebih agung jika kita memaknai diri kita yang belum bisa berdamai dengan diri kita sendiri sebagai belum matang secara religius.

Kemarahan dan makian ini biasanya datang dari komunitas beragama yang kecil. Sebaliknya kita yang datang dari komunitas religius besar, pantaskah kita merasa bangga, menang, dan kuat setelah mampu menghalangi komunitas religius kecil yang ingin menjalankan kebebasan beragamanya. Jika kita merasa pantas dengan kebanggaan, kemenangan, dan kekuatan karena telah mampu membuat komunitas religius kecil tak berdaya, maka sungguh kita telah jatuh sedalamdalamnya dari makna agung keberagamaan sejati. Keberagamaan kita hancur karena kecongkakan jiwa kita karena merasa paling benar tindakan religiusnya. Keberagamaan yang benar tampaknya merupakan keberagamaan yang selalu bisa harmoni dengan dirinya sendiri meski harus memberi ruang kebebasan beragama dari orang beragama yang berbeda. Demikian juga dari pihak yang telah diberi ruang kebebasan beragamanya harus bisa berdamai dengan hatinya sendiri dengan menghargai orang beragama yang telah memberi ruang kebebasan beragama kepada dirinya. Diri religius sejati adalah diri yang selalu meluap kebahagiaannya ketika diri-diri lain yang berbeda agama dan kepercayaan bisa menjalankan kebebasan beragama dan memeluk kepercayaan mereka. Jika setiap diri religius bisa menangkap makna religiusitas sejati maka konflik-konflik religius yang terjadi dilihatnya sebagai medan ujian bagi kualitas keberagamaan untuk selalu menjadi lebih baik dan lebih baik. 
Konflik religius harus dilihat sebagai ruang komunikasi di antara pihak-pihak yang terlibat konflik untuk saling mengasah kedewasaan dalam beragama. Banyak kita temukan orang yang menjadi hinduis, buddhis, kristiani, muslim dan lain sebagainya, tetapi bisakah kita menemukan banyak hinduis, buddhis, kristiani, muslim dan lain sebagainya yang matang keberagamaan mereka di Indonesia. Memang banyak orang hindu, memang banyak orang Buddha, memang banyak orang kristiani, dan memang banyak orang muslim di Indonesia, namun sedikit orang hindu, sedikit orang Buddha, sedikit orang kristiani, dan sedikit orang muslim yang matang keberagamaan mereka di Indonesia. Banyak orang beragama, tetapi sangat sedikit barangkali yang dewasa atau matang keberagamaannya.

\section{Resolusi Konflik Keagamaan di Indonesia}

Resolusi konflik bagi Mc Cartney berarti suatu upaya manusia untuk mengatasi konflik yang terjadi di antara manusia tidak lain hanya untuk tujuan menganjurkan hubungan-hubungan komunitas yang baik. ${ }^{11}$ Sementara yang dipandang penting dari resolusi konflik bagi Samsu Rizal Panggabean, menyepakati pandangan Hugh Miall, Oliver Ramsbotham, dan Tom Woodhouse, adalah menghindarkan konflik dari pecahnya kekerasan fisik dan apalagi bersenjata. Tampak dalam pandangannya bahwa resolusi konflik memiliki makna pengelolaan konflik untuk tidak berkembang menjadi kekuatan destruktif, melainkan menjadi kekuatan konstruktif. Dalam makna resolusi konflik seperti ini diasumsikan bahwa kekerasan fisik dan bahkan bersenjata bukannya tidak bisa dihindari. Kekerasan fisik dan bahkan bersenjata bisa dijauhkan dari terjadi asalkan cara-cara dan usaha-usaha tertentu dibuat, dan inilah yang dimaksudkannya dengan resolusi konflik. ${ }^{12}$

11 Clem McCartney, "Approaches To Ethnic And Religious Conflict Resolution: Managing, Resolving Or Transforming" dalam Taryono (ed.), The Making of Ethnic and Religious Conflicts in Southeast Asia: Cases and Resolutions (Yogyakarta, Penang: Center for Security and Peace Studies (CSPS) Universitas Gadjah Mada \& Southeast Asian Conflict Studies Network (SEACSN) Universiti Sains Malaysia, 2004), 69.

12 Samsu Rizal Panggabean, "Approaches to Ethnic and Religious Conflict Resolution" dalam Taryono (ed.), The Making of Ethnic and Religious Conflicts in Southeast Asia: Cases and Resolutions. (Yogyakarta, Penang: Center for Security and Peace Studies (CSPS) Universitas Gadjah Mada \& Southeast Asian Conflict Studies Network (SEACSN) Universiti Sains Malaysia, 2004), 54-57; lihat juga Hugh Miall, Oliver Ramsbotham, and Tom Woodhouse, Contemporary Conflict Resolution (Cambridge: Polity Press, 1999), 96. 
Batasan pengertian ini memunculkan persoalan apakah penanganan konflik dengan menggunakan kekuatan fisik dan bersenjata -karena alasan jalan komunikasi dan rekonsiliasi dipandang buntu, dan bila dibiarkan berpotensi besar memunculkan konflik yang lebih parah - tidak bisa dibenarkan dalam pengertian resolusi konflik. Perdebatan mengenai apakah resolusi konflik harus selalu diartikan tanpa penggunaan kekerasan atau tidak merupakan persoalan yang menarik untuk didiskusikan. Lepas dari pertanyaan ini, penulis sendiri mengakui bahwa resolusi konflik yang ideal dan sejati memang penanganan konflik yang tanpa menggunakan kekerasan.

Prinsip utama dalam resolusi konflik adalah prinsip berkeadilan dan setara dalam memperlakukan para pihak yang terlibat konflik. Cara terbaik untuk mengimplementasikan prinsip ini adalah memecahkan dan mengatasi masalah-masalah yang dipertentangkan dari dalam kesadaran dan kemauan para pihak yang berkonflik, bukan dipaksakan dari luar mereka. pokok dari resolusi konflik adalah proses mediasi atau menengahi pihak-pihak yang berkonflik untuk memperoleh pemecahan yang saling menguntungkan. Sebelum melakukan proses mediasi penanganan konflik, siapa pun yang ingin menangani dan mengatasi suatu konflik, hal pertama yang harus diperhatikan, harus mengerti dengan baik apa itu konflik. Penjelasan di atas mengenai makna konflik harus dijadikan pegangan.

Noel, Shoemake, dan Hale merangkum makna konflik yang dimaksud untuk kepentingan resolusi konflik sebagai berikut: [1] konflik merupakan suatu aspek alamiah dari kehidupan dan harus dilihat secara konstruktif; [2] konflik memperkuat orang untuk menegaskan diri mereka sendiri dan berkomunikasi secara efektif, bukan hanya membangun karakter tetapi juga mengembangkan otonomi personal, efikasi diri yang positif, dan kerangka referensi yang lebih realistis; [3] konflik berhubungan dengan pembelajaran untuk mengenal emosi-emosi sebagai bagian penting dari komunikasi efektif antar perasaan-perasaan personal; dan [4] konflik berkaitan dengan penunggangan perspektif-perspektif orang lain, mengurangi kesenangan pada reaksi-reaksi keras atau kurang pantas sambil membangun empati. ${ }^{13}$

${ }^{13}$ Brett R Noel, Ann Torfin Shoemake, and Claudia L. Hale, "Conflict Resolution in a Non-Western Context: Conversations with Indonesian Scholars and Practitioners" dalam Conflict Resolution Quarterly, vol. 23, no. 4, Summer (2006): 430431. 
Dalam menangani konflik, orang tidak boleh condong pada yang kuat, berkuasa, dan kaya, tetapi juga tidak boleh hanya mementingkan yang lemah, yang dikuasai, dan yang miskin. Kedua sisi ini pasti ada dalam setiap konflik, makanya perlakuan yang berimbang dan berkeadilan terhadap semua pihak yang terlibat konflik menentukan keberhasilan penanganan konflik dan menggiring mereka ke dalam kesadaran konflik sebagai pembelajaran berharga untuk menentukan kebersamaan mereka yang lebih berkualitas di masa depan.

Ada beberapa pemikir yang mencoba memberikan prinsipprinsip mediasi dalam resolusi konflik di antaranya Andrea Morrison, dan Jean Poitras and Pierre Renaud, dan Fiadjoe. Bagi Morisson, ${ }^{14}$ ada lima prinsip mediasi yang harus ada, yaitu sebagai berikut:

1. Mediasi adalah proses pemecahan masalah; parameter ditentukan oleh pihak-pihak yang terlibat konflik (Problem solving process: parameters defined by parties).

2. Pendekatan berbasis kepentingan dengan fokus pada masa depan (Interest based approaches with 'future' focus).

3. Penciptaan sesering mungkin pihak-pihak yang berkonflik saling berbicara secara langsung (Parties often speak directly to each other).

4. Fakta-fakta dan penalaran adalah penting (Facts and reasoning are important).

5. Kesepakatan yang didasarkan pada hasil saling memuaskan (Agreement based on mutual satisfaction).

Sementara bagi Poitras dan Renaud, ${ }^{15}$ prinsip mediasi terdiri dari empat hal, yaitu:

1. Pencegahan Konflik dari Eskalasinya (Prevent conflict from escalating),

2. Rekonsiliasi kepentingan-kepentingan (Reconcile interests),

3. pencarian suatu solusi saling memberi atau menguntungkan (Seek a mutual-gain solution),

4. pengoordinasian usaha kerja sama pihak-pihak yang berkonflik (Coordinate party effort).

Fiadjoe $^{16}$ menyebut lebih banyak prinsip mediasi, yaitu ada sembilan prinsip atau ciri umum, sebagai berikut:

14 Andrea Morisson, "Module Workshop The Trainers Training of Alternative Dispute Resolution"58.

15 Jean Poitras and Pierre Renaud, Mediation and Reconciliation of Interest in Public Disputes, (Ontario: Carswell Thomson Professional Publishing, 1997), 35.

16 Albert Fiadjoe, Alternative Dispute Resolution: A Developing World Perspective,(

London. Sydney, Portland, Oregon: Cavendish Publishing Limited, 2004 ), 59-60. 
1. Netralitas mediator (Neutrality of mediator),

2. Hakikat otoritas mediator; mediator tidak memiliki otoritas untuk memaksakan penyelesaian pada pihak-pihak yang berselisih (Nature of the mediator's authority; The mediator has no authority to impose a settlement on the disputants),

3. Resolusi konsensual (Consensual resolution),

4. Pemaksimalan kepentingan-kepentingan (Maximisation of interests),

5. Penetapan lingkungan yang aman (Provision of secure environment),

6. Penawaran kerahasiaan (Offer of confidentiality),

7. Ketidakmampuan menawarkan saran independent (Inabiity to offer independent advise),

8. Pemberdayaan pihak-pihak yang berkonflik (Empowerment of parties),

9. Pemeliharaan hubungan (Maintenance of relationships).

Dari ketiga pendapat ini, prinsip-prinsipnya dapat dikombinasikan menjadi sebagai berikut: Mediasi adalah proses pemecahan masalah; parameter ditentukan oleh pihak-pihak yang terlibat konflik, rekonsiliasi dan pemaksimalan kepentingankepentingan, pengondisian sesering mungkin pihak-pihak yang berkonflik saling berbicara secara langsung, pemeliharaan hubungan, pemberdayaan pihak-pihak yang berkonflik, pentingnya fakta-fakta dan penalaran, pengoordinasian usaha kerja sama pihak-pihak yang berkonflik, dan kesepakatan yang didasarkan pada hasil saling memuaskan dan menguntungkan yang berorientasi ke masa depan.

Resolusi konflik untuk konflik-konflik keagamaan di Indonesia sebenarnya telah sering dilakukan oleh orang-orang beragama sendiri, di samping oleh pihak-pihak lain seperti pemerintah. Konflik antara kelompok kristiani dan muslim tertentu, dan antara kelompok hindu dan muslim tertentu, misalnya, selalu ada kelompok kristiani, hindu, dan muslim lain yang merasa prihatin dan mendorong untuk melakukan upaya-upaya pengharmonian kembali. Yang ingin ditekankan di sini dari ungkapan ini adalah bahwa setiap orang beragama bisa menjadi mediator yang baik untuk menangani konflikkonflik religius yang terjadi demi pembangunan kedamaian dan keharmonian hidup religius. Tentu saja membangun hidup beragama yang damai dan komunikatif tidak hanya dilakukan oleh orang-orang beragama saja, apalagi oleh tokoh-tokoh agama saja tetapi banyak pihak yang bisa berperan. David Litte dan Scott Appleby

Pembangunan perdamaian religius memiliki arti yang tidak jauh beda dengan pembangunan perdamaian secara umum. Ia 
menggambarkan lingkup aktivitas-aktivitas yang dilakukan oleh pelaku-pelaku dan institusi-institusi religius yang bermaksud untuk memecahkan dan menransformasikan konflik yang membahayakan. Maksud tersebut memiliki tujuan untuk membangun hubunganhubungan sosial dan institusi-institusi politik yang dicirikan dengan suatu semangat toleransi dan tanpa kekerasan. Pembangunan perdamaian religius tidak hanya berarti melakukan usaha-usaha manajemen dan resolusi konflik di tempat-tempat konflik. Ia juga dipengaruhi kuat oleh usaha-usaha orang yang bekerja jauh di luar tempat-tempat terjadinya konflik, seperti advokat-advokat hukum tentang hak-hak asasi religius manusia, sarjana-sarjana yang melakukan riset yang berkaitan dengan dialog lintas budaya dan lintas agama, dan teolog serta para ahli etika dalam komunitas-komunitas agama yang menanggulangi dan memperkuat tradisi-tradisi anti kekerasan mereka. ${ }^{17}$

Siapa pun yang ingin terlibat melakukan pembangunan perdamaian religius di Indonesia dan melakukan upaya-upaya resolusi konflik, maka prinsip-prinsip dasar mediasi dalam resolusi konflik di atas harus diindahkan. Upaya mediasi atau rekonsiliasi, atau dalam konsep Islam dikenal dengan istilah shulh, bertujuan untuk mempromosikan, memperjuangkan dan mewujudkan perdamaian. Sebelum mengurai langkah-langkah resolusi konflik yang seperti apakah untuk meminimalkan konflik religius di Indonesia, oleh karena itu, perlu dimengerti dulu apa yang dimaksudkan dengan perdamaian.

Menurut Dower, Perdamaian bisa dipahami dalam pengertian negatif dan positif. Pertama pengertian negatif, peace is a minimal relation between different human beings or groups of human beings. "...It exists when there is no war or active violence between the parties in volved." (perdamaian adalah suatu hubungan minimal antara orang atau kelompokkelompok orang yang berbeda-beda ... Ia ada ketika tidak ada perang atau kekerasan aktif antara kelompok-kelompok yang terlibat); Kedua pengertian positif, terinspirasi dari pemikir Macquarrie dan Curle, 'Peace ... is regarded as a state of harmony or wholeness, 'shalom' or a set of peaceful relationships between people and groups characterized by love, mutual

17 David Litte and Scott Appleby, "A Moment of Oppurtunity? The Promise of Religious Peacebuilding in an Era of Religious and Ethnic Conflict", dalam Harold Coward and Gordon S. Smith (eds.), Religion and Peacebuilding (Albany, New York: State University of New York Press, 2004), 5.

18 Nigel Dower, An Introduction to Global Citizenship (Edinburgh: Edinburgh University Press, 2003), 69. 
respect, sence of justice, or lack of fracture." (Perdamaian ... dianggap sebagai suatu keadaan harmoni atau keutuhan, "shalom" atau sederet hubungan-hubungan damai antar orang dan kelompok-kelompok orang yang dicirikan dengan cinta, salang menghargai, rasa keadilan, atau kurangnya perpecahan).

Pandangan Islam tentang perdamaian diperkuat dengan salah satu pemikir muslim Amerika, J.E. Rash yang menegaskan bahwa Islam lebih mengapresiasi perdamaian dalam pengertian positif, karena perdamaian, keamanan, kasih sayang yang sesungguhnya sebenarnya merupakan dimensi spiritualitas manusia. J.E. Rash memandang perdamaian sebenarnya ada di dalam diri manusia itu sendiri, dan itulah mengapa definisi perdamaiannya seperti berikut ini:

"Peace is composed of attributes that enter and exit our hearths and minds throughout our lives. Peace comes in moments of compassion, of patience, of error and repentance, of forgiveness. It comes in bursts of creativity, in the awareness of limitations, in a sense of destiny. ...peace depends on more than structures, on more than laws, and more than social principles. It depends on establishing peace within buman beings. ${ }^{, 20}$

(Perdamaian terdiri dari sifat-sifat yang memasuki dan keluar dari hati-hati dan pikiran-pikiran kita sepanjang hidup kita. Perdamaian masuk dalam momen-momen belas kasih, kesabaran, kesalahan dan pertobatan, dan pengampunan. Ia masuk dalam ledakan-ledakan kreativitas, dalam kesadaran atas keterbatasan-keterbatasan, dalam suatu perasaan takdir. ... perdamaian bergantung pada lebih dari sekedar struktur-struktur, pada lebih dari sekedar hukum-hukum, dan lebih dari sekedar prinsip-prinsip sosial. Ia bergantung pada penegakan perdamaian di dalam diri manusia).

Pengalaman-pengalaman konflik manusia telah memberinya pengalaman-pengalaman berbuat salah atau bahkan kejam, memandang rendah orang lain, mau menang sendiri, dan seterusnya; dan juga telah memberinya pengalaman-pengalaman direndahkan, dicibirkan, dihina, ditipu, dipinggirkan, dianiaya, dan seterusnya. Menyikapi secara positif pengalaman-pengalaman tersebut, orang menjadi sadar dari kesalahannya, memohon ampun dan maaf, dan mulai mencoba menghargai eksistensi orang atau masyarakat lain; orang menerima kenyataan dengan kesabaran, tidak membalas, dan

${ }^{19}$ Ibid. Lihat J. Macquarrie, The Concept of Peace (New York: Harper and Row, 1973) dan A. Curle, True Justice (London: Quaker Home Service, 1981).

${ }^{20} \mathrm{~J}$.E. Rash, Islam and Democracy: A Foundation for ending extrimsm and preventing conflict (Wingspan, 2006),31. 
mudah memberi maaf. Orang, masyarakat, dan negara dari waktu ke waktu mengaca pada pengalaman-pengalaman yang mungkin tidak diinginkan manusia seperti konflik dan peperangan. Mereka belajar mengerti keinginan, kebutuhan, dan kepentingan pihak lain, belajar menghubungkan keinginan, kebutuhan, dan kepentingan pihak lain itu dengan keinginan, kebutuhan, dan kepentingan mereka sendiri dengan cara-cara yang baik di bawah spirit cinta-kasih kemanusiaan dan saling menghargai satu sama lain. Dalam proses inilah perdamaian yang sesungguhnya bisa diharapkan. ${ }^{21}$

Konflik-konflik keagamaan di Indonesia harus ditangani terutama oleh orang-orang religius Indonesia itu sendiri, karena tidak ada agama yang mengajarkan kekerasan. Setiap agama pasti menganjurkan kebaikan dan kedamaian. Jika konflik-konflik antar orang beragama terjadi, berarti masih ada masalah dalam beragama kita. Kesalahan ini bukan dari ajaran agamanya, melainkan dari ajaran orang beragamanya. Orang-orang beragama yang sadar akan hal ini sebagai ketidakmatangan dalam beragama harus mengambil inisiatif untuk memperbaiki cara beragama yang baik dan manusiawi. Salah satu, yang paling mudah dipahami, dari ciri beragama yang baik adalah sikap membenci egoisme, kekerasan dan ketidakadilan, dan menganjurkan kerja sama, toleransi, dan keadilan yang muncul dari kesadaran dari dalam diri manusia beragama itu sendiri, bukan dari luar atau dipaksakan melalui kekuasaan.

Pemuka-pemuka agama dan para intelektual dan peneliti agama di Indonesia harus diberdayakan menjadi motor mediasi dan rekonsiliasi atas konflik-konflik religius yang ada. Sebagai motor berarti mereka mengondisikan sebanyak mungkin manusia beragama sebagai mediator dan pemersatu hidup dalam masyarakat. Para mediator ini pada gilirannya akan menggerakkan institusi-institusi keagamaan dan masyarakat mereka menjadi agen-agen peacebuilder of religious life, dan mendorong negara untuk menjadi penguat membangun kedamaian religius secara netral dan lepas dari sikapsikap yang menunjukkan favoritisme keagamaan. Dengan prinsipprinsip mediasi yang telah diurai di atas, manusia-manusia religius sebagai mediator konflik-konflik keagamaan mendorong komunitaskomunitas religius yang berbeda-beda di Indonesia menemukan common ground yang bisa saling merasa saling puas dan saling

${ }^{21}$ Alim Roswantoro, "Islam dan Pembangunan Perdamaian: Mengenal Pemikiran J.E. Rash" dalam Teologia Jurnal Ilmu-ilmu Ushuluddin, Fakultas Ushuluddin IAIN Walisongo Semarang, vol 20, Nomor 1( Januari 2009) : 189. 
diuntungkan sehingga kepentingan-kepentingan masing-masing bisa saling didapatkan tanpa cara-cara kekerasan. Beberapa hal yang bisa dilakukan sebagai ijtihad merubah wajah kehidupan religius Indonesia ke depan yang lebih baik, dan ini sebagai upaya resolusi konflik sepanjang hayat di antaranya adalah sebagai berikut:

1. Mengajak orang-orang beragama, baik yang belum pernah terlibat konflik maupun yang pernah terlibat konflik, berpikir dari realitas keragaman fakta agama dan keragaman fakta keberagamaan, dengan mendiskusikan bagaimana agama-agama yang berbeda itu ada, bagaimana pengaruh-pengaruh budaya dalam proses pemahaman keagamaan, dan bagaimana pentingnya membangun saling belajar dari perbedaan, merupakan hal yang harus diberikan di komunitas-komunitas agama masing-masing melalui forumforum keagamaan maupun pendidikan-pendidikan keagamaan di sekolah.

2. Menjadikan komunitas-komunitas religius dan budaya yang beragam agama/keyakinan dan beragam etnis sebagai laboratorium pembelajaran agama pluralistik-multikultural. Pendekatan yang dipakai jangan sekedar idea to idea approach, melainkan person to person or people to people approach. Jangan sekedar memberikan sederet teoriteori mengenai perbedaan, tetapi kondisikan mereka untuk bercerita mengenai dunia budaya dan agama masing-masing dengan menunjukkan suka-duka, harapan yang diinginkan dan tidak diinginkan, dan kemudian berbagai bersama secara komunikatif dan menemukan harapan bersama apa yang diinginkan dan tidak diinginkan, dan sikap-perilaku apa yang mereka bersama kehendaki dan tidak kehendaki untuk bisa saling memberi ruang eksistensi masing-masing.

3. Memberi pengalaman langsung mengenai kegiatan bersama yang bersifat lintas agama dan lintas budaya. Kegiatan semacam ini memerlukan suatu desain pembelajaran yang bersifat kolaboratif antar komunitas-komunitas religius yang beragama tersebut. Muatan kegiatan sebaiknya lebih bersifat sosial daripada religius, yakni bukan bicara masalah doktrin religius, tetapi bekerja bareng dalam urusan-urusan sosial-kemanusiaan. Tujuan dasarnya adalah menanamkan perasaan tanggung jawab bersama atas berbagai persoalan publik di ruang publik. Di ruang privat, masing-masing memiliki aturan kepercayaan dan moral sendiri-sendiri, namun di ruang publik, ada aturan main bersama yang sama-sama harus 
dijunjung tinggi untuk memperkuat kemanusiaan "tanpa baju" perbedaan.

4. Pengetahuan dan ketrampilan mengenai conflict resolution dan peacebuilding sangat penting diberikan kepada orang-orang beragama yang hidup dalam masyarakat yang multireligius dan multikultural. Dalam kehidupan yang pluralistik-multikultural, perbedaanperbedaan berpotensi kuat memunculkan gesekan-gesekan, ketegangan-ketegangan, dan konflik-konflik. Tanpa pengetahuan dan ketrampilan melakukan penanganan konflik dan pembangunan perdamaian tidak akan terjadi penguatan masyarakat pluralistikmultikultural. Yang terpenting dari hal ini adalah bahwa pembiasaan sikap hidup yang tidak merendahkan, menghina, melecehkan, dan melukai orang karena ia berbeda merupakan pencegahan yang efektif untuk memunculkan ketegangan dan konflik. Prinsip-prinsip resolusi konflik yang telah diurai di atas harus dikenal dengan baik oleh sebanyak mungkin manusia beragama di Indonesia. Tempat-tempat ibadah, forum-forum agama, sekolah, dan lain sebagainya merupakan sarana strategis untuk memberikan pengetahuan dan ketrampilan ini.

5. Membuat forum-forum lintas agama/iman untuk menjalankan kegiatan pemberdayaan sosial dan kegiatan berekonomi. Membentuk kelompok-kelompok masyarakat yang terdiri dari komunitas lintas agama untuk pemberdayaan sosial dan ekonomi masyarakat pedesaan dan pinggiran kota berbasis keagamaan sangat strategis untuk saling mendekatkan kesadaran bersama sebagai manusia meskipun berbeda tetapi saling memberdayakan untuk kepentingan sosial bersama dan pemenuhan kecukupan hidup secara ekonomi.

\section{Penutup}

Resolusi konflik-konflik religius yang terbaik adalah resolusi yang dibangun dari dalam umat beragama itu sendiri. Apa yang kita ketahui dari Islam, Kristen, dan agama-agama lainnya adalah orang harus bertanggungjawab terhadap diri mereka sendiri dan melalui pengalaman-pengalaman hidup mempertahankan kehidupan yang damai, aman, dan nyaman. Perasaan damai, saling menghargai, saling memberdayakan dari suatu masyarakat religius yang beragam akan lebih bertahan lama dan fundamental sifatnya jika datang dari dalam masyarakat religius yang beragam itu sendiri, daripada dari luar mereka. Tentu saja mengondisikan perdamaian religius dari luar bukan hal yang buruk malah memang tidak bisa dihindari untuk 
dilakukan. Namun hanya berhenti di sini tidaklah cukup dan harus diikuti dengan proses penanaman nilai-nilai moral kemanusiaan secara terus-menerus yang dipandang sebagai inti sari dari pembangunan perdamaian religius, sehingga akan tumbuh kesadaran dari dalam betapa pentingnya perdamaian religius.

Perdamaian religius tak mungkin terwujud tanpa kesadaran nilainilai etis yang tumbuh dalam diri manusia beragama untuk menopang perwujudannya. Tetapi harus diingat pula tentang perdamaian religius dari luar bahwa untuk mengondisikan perdamaian dari luar tentu tidak boleh dengan paksaan yang mengorbankan kebebasan manusia baik secara individu maupun kolektif, karena cara ini kontra produktif dengan hakikat perdamaian itu sendiri dan dekat dengan kekerasan. Kekuatan-kekuatan dari luar seperti dari institusi-institusi politik memang penting, tetapi ini akan rapuh kalau tidak ada kesadaran dari dalam masyarakat religius itu sendiri. Tugas resolusi konflik religius bukan tugas-tugas musiman melainkan tugas sepanjang masa. 


\section{Daftar Pustaka}

Abdullah, M. Amin. "Peran Pemimpin Politik dan Agama dalam Mengurai dan Resolusi Konflik dan Kekerasan." Dalam Alim Roswantoro dan Abdul Mustaqim (ed.). Antologi Isu-isu Global dalam Kajian Agama dan Filsafat. Yogyakarta: Prodi Agama dan Filsafat Pascasarjana UIN Sunan Kalijaga dan Penerbit Idea Press, 2010.

Chandra, Robby I. Konflik dalam Hidup Sehari-hari. Yogyakarta: Penerbit Kanisius, 1992.

Coward, Harold and Smith, Gordon S.. (eds.). Religion and Peacebuilding.

Albany, New York: State University of New York Press, 2004.

Curle, A. True Justice.London: Quaker Home Service, 1981.

Dower, Nigel. An Introduction to Global Citizenship. Edinburgh: Edinburgh University Press, 2003.

Fiadjoe, Albert. Alternative Dispute Resolution: A Developing World Perspective. London. Sydney, Portland, Oregon: Cavendish Publishing Limited, 2004.

Fuller, Graham E.. A World Without Islam. New York: Little, Brown and Company, 2010.

Litte, David and Appleby, Scott. "A Moment of Oppurtunity? The Promise of Religious Peacebuilding in an Era of Religious and Ethnic Conflict." Dalam Harold Coward and Gordon S. Smith (eds.). Religion and Peacebuilding. Albany, New York: State University of New York Press, 2004.

Macquarrie, J. The Concept of Peace. New York: Harper and Row, 1973.

McCartney, Clem. "Approaches To Ethnic And Religious Conflict

Resolution: Managing, Resolving Or Transforming." Dalam Taryono (ed.). The Making of Ethnic and Religious Conflicts in Southeast Asia: Cases and Resolutions. Yogyakarta, Penang: Center for Security and Peace Studies (CSPS) Universitas Gadjah Mada \& Southeast Asian Conflict Studies Network (SEACSN) Universiti Sains Malaysia, 2004.

Mc'Ternan, Oliver. Violence in God's Name. London: Darton, Longman Todd Ltd., 2003.

Miall, Hugh; Ramsbotham, Oliver; and Woodhouse, Tom. Contemporary Conflict Resolution. Cambridge: Polity Press, 1999.

Murray, Henry. Explorations in Personality. New York: Oxford University, 1938.

Noel, Brett R.; Shoemake, Ann Torfin; and Hale, Claudia L. "Conflict Resolution in a Non-Western Context: Conversations with 
Indonesian Scholars and Practitioners." Conflict Resolution Quarterly, vol. 23, no. 4, Summer 2006.

Panggabean, Samsu Rizal. "Approaches to Ethnic and Religious Conflict Resolution." Dalam Taryono (ed.), The Making of Ethnic and Religious Conflicts in Southeast Asia: Cases and Resolutions. Yogyakarta, Penang: Center for Security and Peace Studies (CSPS) Universitas Gadjah Mada \& Southeast Asian Conflict Studies Network (SEACSN) Universiti Sains Malaysia, 2004.

Poitras, Jean and Renaud, Pierre. Mediation and Reconciliation of Interest in Public Disputes. Ontario: Carswell Thomson Professional Publishing, 1997.

Roswantoro, Alim dan Mustaqim, Abdul (ed.). Antologi Isu-isu Global dalam Kajian Agama dan Filsafat. Yogyakarta: Prodi Agama dan Filsafat Pascasarjana UIN Sunan Kalijaga dan Penerbit Idea Press, 2010.

Roswantoro, Alim. "Islam dan Pembangunan Perdamaian: Mengenal Pemikiran J.E. Rash" dalam Teologia Jurnal Ilmu-ilmu Ushuluddin, Fakultas Ushuluddin IAIN Walisongo Semarang, vol 20, Nomor 1, Januari 2009.

Sacks, Jonathan. Not in God's Name: Confronting Religious Violence. Edinburg: Hodder \& Stoughton, An Hachette UK Company, 2015.

Taryono (ed.). The Making of Ethnic and Religious Conflicts in Southeast Asia: Cases and Resolutions. Yogyakarta, Penang: Center for Security and Peace Studies (CSPS) Universitas Gadjah Mada \& Southeast Asian Conflict Studies Network (SEACSN) Universiti Sains Malaysia, 2004. 